Nicholas, D. J. D. (1956). J. gen. Microbiol. 15, 470-477

\title{
Trace Metal Requirements and some Enzyme Systems in a Riboflavin-requiring Mutant of Neurospora crassa
}

\author{
BY D. J. D. NICHOLAS \\ A.R.C. Unit of Plant Nutrition (Micronutrients), Long Ashton Research Station, \\ University of Bristol
}

SUMMARY: A mutant of Neurospora crassa is shown to have an absolute requirement for riboflavin when grown at $30^{\circ}$, but this requirement is less stringent when the organism is grown at $25^{\circ}$. The $\mathrm{Fe}, \mathrm{Cu}, \mathrm{Zn}, \mathrm{Mn}$ and Mo requirements of the mutant, grown at either temperature, are similar to those of the wild type (146) so that it seems unlikely that these metals are involved in the biosynthesis of riboflavin. A study of enzyme patterns in the mutant, grown at $30^{\circ}$ and given optimal or deficient concentrations of riboflavin, demonstrated alternative pathways of electron transfer in the fungus. When riboflavin is deficient, the iron enzymes are markedly increased and oxygen is probably the main terminal acceptor of the electrons. At optimal concentrations of riboflavin, the flavoprotein enzymes are produced and nitrate and nitrite reductases are active so that nitrate can act as a terminal acceptor. Iron deficiency is readily produced in the mutant when riboflavin is deficient because of the increased activity of iron enzymes; a molybdenum requirement is greater at optimal riboflavin concentrations because of the enhanced production of molybdoflavoproteins.

Mitchell \& Houlahan (1946) showed that in a temperature-sensitive mutant of Neurospora crassa a riboflavin requirement shown during growth at $30^{\circ}$ was eliminated by growing the fungus at $25^{\circ}$. In the present investigation the trace metal requirements of this mutant grown at the two temperatures were determined as well as some of the enzyme changes which occurred when the fungus was grown at $30^{\circ}$ with optimum or deficient concentrations of riboflavin.

\section{METHODS}

Mutant. The riboflavin-requiring mutant of Neurospora crassa which is temperature-sensitive was kindly supplied by Dr A. Mitchell, California Institute of Technology, U.S.A.

Culture medium. The mutant was grown in the following medium: sucrose, 20 g.; $\mathrm{NH}_{4} \mathrm{NO}_{3}, 20$ g.; $\mathrm{Na}$ tartrate, 1 g.; $\mathrm{KH}_{2} \mathrm{PO}_{4}, 3$ g.; $\mathrm{MgSO}_{4} .7 \mathrm{H}_{2} \mathrm{O}, 0.5$ g.; $\mathrm{NaCl}, 0 \cdot 1$ g.; $\mathrm{CaCl}_{2}, 0 \cdot 1 \mathrm{~g}$; ; biotin, $5 \mu \mathrm{g}$.; $\mathrm{FeCl}_{3} .6 \mathrm{H}_{2} \mathrm{O}, 9 \cdot 6 \times 10^{-4} \mathrm{~g}$.; $\mathrm{ZnSO}_{4} .7 \mathrm{H}_{2} \mathrm{O}$, $8.8 \times 10^{-3}$ g.; $\quad \mathrm{CuCl}_{2} .2 \mathrm{H}_{2} \mathrm{O}, \quad 2 \cdot 7 \times 10^{-4} \mathrm{~g} . ; \quad \mathrm{MnCl}_{2} .4 \mathrm{H}_{2} \mathrm{O}, \quad 7 \cdot 2 \times 10^{-5}$ g.; $\mathrm{Na}_{2} \mathrm{MoO}_{4} \cdot 2 \mathrm{H}_{2} \mathrm{O}, 1 \cdot 2 \times 10^{-5} \mathrm{~g}$.; distilled water, 1 litre.

Purification of culture media. The methods used to remove trace metals from the macronutrients were described elsewhere (Nicholas, 1952). The micronutrient elements, $\mathrm{Fe}, \mathrm{Cu}, \mathrm{Zn}, \mathrm{Mn}$ and Mo were as 'spectroscopically pure' compounds supplied by Johnson \& Matthey (Hatton Garden, London, E.C. 1). Biotin (25 $\mu \mathrm{g}$.) dispensed in phosphate buffer ( $\mathrm{pH} \mathrm{7)}$ was supplied in ampoules by the Ashe Laboratories (Leatherhead, Surrey). Riboflavin dispensed in glass-distilled water in an amber bottle was stored in the dark at $0^{\circ}$. The culture 
medium (100 ml.) was dispensed in $500 \mathrm{ml}$. Erlenmeyer flasks, and after sterilizing at $10 \mathrm{lb}$./sq.in. for $15 \mathrm{~min}$. and cooling, these were inoculated with a mycelial suspension of the mutant in glass-distilled water. Before inoculating and incubating the flasks at $30^{\circ}$, riboflavin was added aseptically $(25 \mu \mathrm{g} . / 100 \mathrm{ml}$.) when optimal growth of the mutant was required. The organism was grown for 4 days at either temperature

Preparation of cell-free extracts. The mycelial mats collected in a Büchner funnel were washed thoroughly with glass-distilled water and were frozen for $3 \mathrm{hr}$. at $-17^{\circ}$. They were then homogenized in three times their weight of cold 0.1 M-phosphate buffer ( $\mathrm{pH} 7 \cdot 5$ ) with a pestle and mortar and then in a Ten Broeck glass macerater at $0^{\circ}$. The homogenate was centrifuged at $2000 \mathrm{~g}$ for $10 \mathrm{~min}$. at $4^{\circ}$. Tris-(hydroxymethyl)-aminomethane buffer $0.1 \mathrm{M}(\mathrm{pH} \mathrm{7.5)}$ was used to extract the 'phosphate' enzymes. The homogenates were dialysed for $12 \mathrm{hr}$. against the same buffers in which they had been prepared.

Cofactors and other compounds. Diphosphopyridine nucleotide (DPN) of $\mathbf{5 0} \%$ purity was prepared from baker's yeast by the method of Kornberg (private communication). Triphosphopyridine nucleotide (TPN) $95 \%$ purity and cytochrome $c$ were obtained from Sigma Chemical Company, U.S.A., and riboflavin-5-phosphate (FMN) from Nutritional Biochemicals Corporation, U.S.A. Reduced DPN was prepared enzymically by the alcohol dehydrogenase method of Pullman, Colowick \& Kaplan (1954) and reduced TPN by using the isocitric dehydrogenase enzyme from acetone powder of pig heart. Boiled pig heart extract, centrifuged at $18,000 \mathrm{~g}$ for $20 \mathrm{~min}$., at $4^{\circ}$ was used as a source of flavine adenine dinucleotide (FAD).

\section{Enzymes assayed}

Catalase activity was measured at $37^{\circ}$ by the perborate method of Feinstein (1949). The reaction mixture contained $8 \mathrm{ml} .1 \cdot 5 \%$ (w/v) $\mathrm{NaBO}_{3} .4 \mathrm{H}_{2} \mathrm{O}$ (pH 6.8); $1.5 \mathrm{ml} .0 \cdot 1 \mathrm{M}$-phosphate buffer (pH 6.8); 0.1 ml. enzyme extract; and was incubated at $37^{\circ}$ for $5 \mathrm{~min}$. Then $10 \mathrm{ml}$. $2 \mathrm{~N}-\mathrm{H}_{2} \mathrm{SO}_{4}$ was added and the solution titrated with $0.05 \mathrm{~N}-\mathrm{KMnO}_{4}$. The values are expressed as mmole perborate degraded in $5 \mathrm{~min} . / \mathrm{mg}$. protein.

Peroxidase was determined by the spectrophotometric method of Smith, Robinson \& Stotz (1949). The reaction mixture contained $1.3 \mathrm{ml}$. of McIlvaine's buffer (pH 6.0); $1.0 \mathrm{ml}$. $10^{-3}$ M-reduced $2: 6$-dichloroindophenol; $0.5 \mathrm{ml}$. $0 \cdot 1 \mathrm{M}-\mathrm{H}_{2} \mathrm{O}_{2} ; 0 \cdot 1 \mathrm{ml}$. enzyme extract. The oxidation of the dye was followed at $625 \mathrm{~m} \mu$. at $15 \mathrm{sec}$. intervals. The unit of activity is the change in log. $I_{0} / I$ of $0.001 / \mathrm{min}$. calculated between 15 and $75 \mathrm{sec} . / \mathrm{mg}$. protein.

Cytochrome oxidase was measured in homogenates of mycelial felts by the method of Smith \& Stotz (1949). The reaction solution contained $1.5 \mathrm{ml}$. 0.2 M-phosphate (pH 6.8); $1.0 \mathrm{ml} .1^{-3}$ M-reduced 2 : 6-dichloroindophenol; $0.5 \mathrm{ml} .1 \times 10^{-4} \mathrm{M}$-cytochrome $c ; 0.2 \mathrm{ml}$. enzyme extract. The units of activity corrected for endogenous rate, are similar to those for peroxidase.

$T P N$-cytochrome c reductase was measured at $551 \mathrm{~m} \mu$. The reaction mixture contained: $2.5 \mathrm{ml}$. 0.1 M-phosphate buffer ( $\mathrm{pH} \mathrm{7.5);0.5} \mathrm{ml.} \mathrm{oxidized} \mathrm{cyto-}$ chrome $c, 3 \times 10^{-4} \mathrm{M} ; 0.1 \mathrm{ml}$. TPNH $(2 \mu \mathrm{mole} / \mathrm{ml}$. $) 0.1 \mathrm{ml}$. enzyme extract. 
$D P N H$ and TPNH oxidases ('diaphorase' systems) were measured by following dye reduction at $625 \mathrm{~m} \mu$. The reaction mixture used was as follows: $2.5 \mathrm{ml} .0 .1 \mathrm{M}$-phosphate $(\mathrm{pH} \mathrm{7.5}) ; 0.3 \mathrm{ml} .1 \times 10^{-3} \mathrm{M}-2$ : 6-dichloroindophenol; $0.1 \mathrm{ml}$. $0.1 \mathrm{M}-\mathrm{KCN}$; $0.1 \mathrm{ml}$. DPNH (10 mg. $/ \mathrm{ml}$.) or TPNH (2 $\mu \mathrm{mole} / \mathrm{ml}$.); $0 \cdot 1 \mathrm{ml}$. enzyme extract.

Nitrate reductase was measured by the method of Nicholas \& Nason (1954). The test procedure consisted of adding $0.1 \mathrm{ml}$. enzyme extract to a solution containing 0.1 ml. 0.1 $\mathrm{M}^{-\mathrm{KNO}_{3}} ; 0.04 \mathrm{ml} .10^{-3} \mathrm{M}-\mathrm{FMN} ; 0.02 \mathrm{ml} .10^{-3} \mathrm{M}-\mathrm{KCN}$; $0.04 \mathrm{ml} .2 \times 10^{-3} \mathrm{M}$-TPNH and $0.30 \mathrm{ml}$. 0.1 M-phosphate (pH 7.5). After $10 \mathrm{~min}$. incubation at $25^{\circ}, 3.5 \mathrm{ml}$. water and $0.5 \mathrm{ml} .1 \%(\mathrm{w} / \mathrm{v})$ sulphanilamide reagent and $0.5 \mathrm{ml} .0 .001 \%(\mathrm{w} / \mathrm{v}) \mathrm{N}$-(1-naphthyl)ethylenediamine dihydrochloride naphthylethylenediamine reagent were added. After $10 \mathrm{~min}$. the test solutions were read on the Spekker absorptiometer at $540 \mathrm{~m} \mu$. Control tests without TPNH were used to correct for the turbidity of the enzyme. Units of activity are expressed as $\mathrm{m} \mu \mathrm{mole} \mathrm{NO}_{2}$ formed/mg. protein in $10 \mathrm{~min}$.

Nitrite reductase was determined by a modification of the method described by Nason \& Zucker (1956). The test consisted of adding $0.1 \mathrm{ml}$. enzyme to a solution containing $0.1 \mathrm{ml} .10^{-3} \mathrm{M}-\mathrm{KNO}_{2} ; 0.05 \mathrm{ml}$. boiled pig heart extract; $0.05 \mathrm{ml}$. DPNH (10 mg./ml.) and $0.2 \mathrm{ml}$. 0.1 $\mathrm{M}$-phosphate buffer (pH 7.5). After $10 \mathrm{~min}$. incubation at $25^{\circ}$ the colour was developed and determined as in the nitrate reductase assay.

The following enzymes were examined in $0 \cdot 1 \mathrm{M}$-tris-(hydroxymethyl)aminomethane ( $\mathrm{pH} 7 \cdot 5)$ extracts of the mycelial felts.

Alkaline phosphatase was estimated by the method of Bessey, Lowry \& Brock (1946) in which the breakdown of $p$-nitrophenylphosphate to $p$-nitrophenol was measured. The enzyme activity is expressed as $\mu$ mole $P$ released in $30 \mathrm{~min}$./mg. protein.

Hexokinase was measured by the method of Crane \& Sols (1953). To $5 \mathrm{ml}$. solution containing $\mathbf{A T P}, \mathrm{MgCl}_{2}$ and bromothymol blue at $2.5 \times 10^{-3} \mathrm{M}$; $5 \times 10^{-3} \mathrm{M}$ and $0.0003 \%(\mathrm{w} / \mathrm{v})$ respectively is added $0.8 \mathrm{ml} .5 \%$ glucose $; 0.2 \mathrm{ml}$. enzyme extract and the solution adjusted to $\mathrm{pH} \mathrm{7 \cdot 4}$. The control cell contained water instead of the enzyme. The change in colour was measured at 5 min. intervals for $30 \mathrm{~min}$. at $620 \mathrm{~m} \mu$. by means of a spectrophotometer. The enzyme activity is expressed as the change in $\log I_{0} / I$ of 0.001 calculated between 5 and $25 \mathrm{~min}$./mg. protein.

Phosphorylase was measured by the method of Whelan (1955). The reaction mixture contained $0.2 \mathrm{ml} .5 \%(\mathrm{w} / \mathrm{v})$ soluble starch; $0.5 \mathrm{ml}$. 0.5 M-citric acid-NaOH buffer ( $\mathrm{pH} \mathrm{6.0);0.1} \mathrm{ml.} \mathrm{enzyme} \mathrm{extract;} 1.7 \mathrm{ml}$. water equilibrated at $35^{\circ}$ for $10 \mathrm{~min}$. and then $1 \mathrm{ml} .0 \cdot 1 \mathrm{~m}$-glucose-1-phosphate added. The reaction was stopped after $10 \mathrm{~min}$. by adding $5 \mathrm{ml} .5 \%(\mathrm{w} / \mathrm{v})$ trichloroacetic acid and after centrifuging at $3000 \mathrm{~g}$ for $10 \mathrm{~min}$. a sample was taken for $\mathrm{P}$ determination. Control tubes were incubated with acid added at the beginning of the reaction. The activity is expressed in $\mu$ mole $P$ formed $/ \mathrm{mg}$. protein.

Phosphoglucomutase was determined by the method of Najjar (1955). The reaction mixture contained $0 \cdot 1 \mathrm{ml} .0 \cdot 1 \mathrm{M}-\mathrm{MgSO}_{4} ; 0 \cdot 1 \mathrm{ml} .0 \cdot 1 \mathrm{M}$-glucose-1-phosphate and $0 \cdot 1 \mathrm{ml} .0 \cdot 1 \mathrm{M}$-cysteine hydrochloride $(\mathrm{pH} 7 \cdot 5$ ) freshly prepared, which 
was equilibrated at $30^{\circ}$ before adding $0.2 \mathrm{ml}$. enzyme extract. The solution was incubated for $10 \mathrm{~min}$. and then $1 \mathrm{ml} .5 \mathrm{~N}-\mathrm{H}_{2} \mathrm{SO}_{4}$ added and the volume made to $5 \mathrm{ml}$. with distilled water. The reaction tubes were put in a boiling water bath to hydrolyse the remaining glucose-1-P. The control tubes were treated with $\mathrm{H}_{2} \mathrm{SO}_{4}$ as above at zero time. $P$ was determined in $1 \mathrm{ml}$. of the reaction mixture. The activity is expressed in $\mu$ mole $\mathrm{P} / \mathrm{mg}$. protein or $\mu$ mole glucose-6-P formed/mg. protein.

Protein was determined by the biuret method of Robinson \& Hogden (1940).

\section{RESULTS}

\section{Riboflavin requirements}

Fig. 1 shows the effect of riboflavin on the growth of the mutant. At $30^{\circ}$ there was no growth unless riboflavin was supplied; at $25^{\circ}$ appreciable growth occurred without added riboflavin. Maximum yield of the organism was however obtained when the fungus was grown at $30^{\circ}$.

\section{Trace metals in relation to growth}

A comparison between the trace metal requirements of Neurospora crassa wild type 146 and the riboflavin-requiring mutant grown at 25 and $30^{\circ}$ is made in Fig. 2. Irrespective of temperature, $\mathrm{Fe}, \mathrm{Zn}, \mathrm{Cu}, \mathrm{Mo}$ and $\mathrm{Mn}$ were all required for optimal growth of the mutant. The dry-weight yields of the mutant were similar to those of the wild type 146 when both were grown at $30^{\circ}$, but these were greater than the weights obtained when the mutant was grown at $25^{\circ}$. The micronutrient requirements for optimal growth of the wild type 146 and of the mutant grown at $25^{\circ}$ or $30^{\circ}$ were similar, being as follows $(\mu \mathrm{g} . / 100 \mathrm{ml}$. medium) : Fe, 15; Zn, 25; Mo, 1; Cu, 2; and Mn, 2.

\section{Enzymes}

Enzyme assays were made in extracts of the mutant grown at $30^{\circ}$ at optimal and deficiency concentrations of riboflavin ( $50 \%$ decrease of weight of fungus). The results for the iron enzymes are given in Table 1. Riboflavin deficiency resulted in a significant increase in peroxidase and cytochrome oxidase. Cytochrome $c$ reductase, which has flavin adenine dinucleotide in the prosthetic group, was markedly less in amount when riboflavin was limiting. Catalase was only slightly depressed.

The results for the flavoprotein enzymes are listed in Table 2. The four flavoprotein enzyme systems were less active in riboflavin-deficient mycelium. The nitrate and nitrite reductase enzymes were more markedly decreased in amount than were the diaphorase systems, so that the riboflavin available appeared to be preferentially utilized in the diaphorase systems. The addition of boiled pig heart extract, a source of FAD, restored the activity of these enzymes (except nitrate reductase), almost to the level of controls, in extracts of deficient felts.

The results of assays for four phosphate enzymes are given in Table 3 . Hexokinase activity was about $30 \%$ higher in riboflavin deficient mycelium. The other three enzymes appear to be unaffected by riboflavin deficiency. 




Fig. 1. Effect of additions of riboflavin on growth of 'riboflavin-requiring' mutant of Neurospora crassa. $\odot-\odot$ growth at $25^{\circ} ; x-x$, growth at $30^{\circ}$.

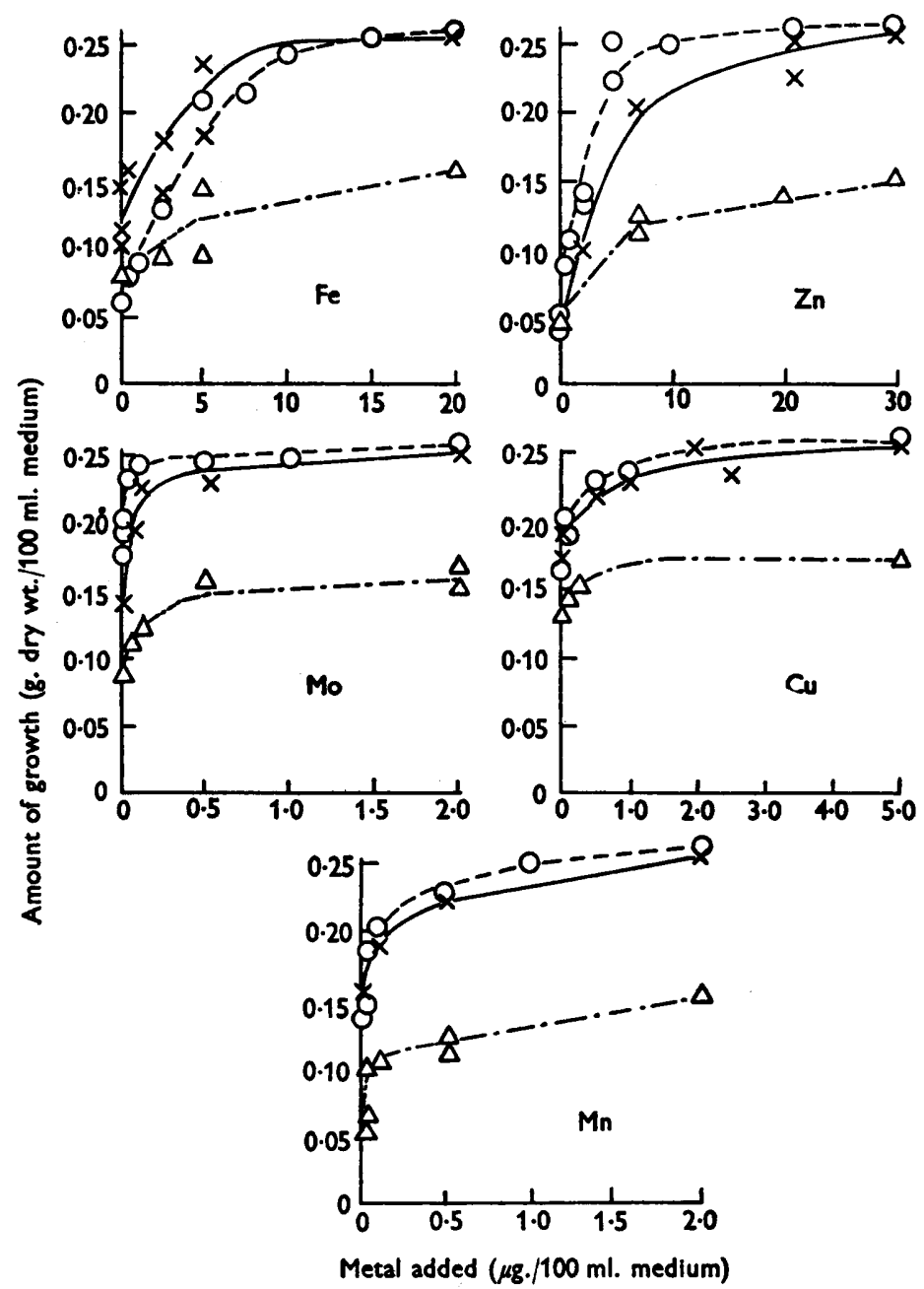

Fig. 2. Effect of trace metals on growth of wild type (146) and 'riboflavin requiring' mutant of Neurospora crassa. $\mathrm{O}_{--}$, wild type at $30^{\circ} ; \Delta-.-\Delta$, mutant at $25^{\circ} ; \times-\times$, mutant at $30^{\circ}$. 
Table 1. Effect of riboflavin deficiency on the iron enzymes in the mycelium of Neurospora crassa mutant grown at $30^{\circ}$

\begin{tabular}{|c|c|c|c|}
\hline \multirow{2}{*}{ Enzyme } & \multirow{2}{*}{$\begin{array}{l}\text { Expt. } \\
\text { no. }\end{array}$} & $\begin{array}{l}\text { Normal } \\
\text { mycelia }\end{array}$ & $\begin{array}{c}\text { Riboflavin-deficient } \\
\text { mycelia }\end{array}$ \\
\hline & & \multicolumn{2}{|c|}{ Units of enzyme activity/mg. protein } \\
\hline Catalase & $\begin{array}{c}10 . \\
\mathbf{1} \\
\mathbf{2} \\
\mathbf{3}\end{array}$ & $\begin{array}{l}1160 \\
1475 \\
1494\end{array}$ & $\begin{array}{r}812,70 \% \text { of normal } \\
1244,85 \% \text { of normal } \\
1256,84 \% \text { of normal }\end{array}$ \\
\hline Peroxidase & $\begin{array}{l}\mathbf{1} \\
\mathbf{2} \\
\mathbf{3}\end{array}$ & $\begin{array}{r}38 \\
54 \\
150\end{array}$ & $\begin{array}{l}91,240 \% \text { of normal } \\
83,154 \% \text { of normal } \\
409,270 \% \text { of normal }\end{array}$ \\
\hline Cytochrome $c$ oxidase & $\begin{array}{l}\mathbf{1} \\
\mathbf{2} \\
\mathbf{3}\end{array}$ & $\begin{array}{l}300 \\
117 \\
668\end{array}$ & $\begin{array}{l}464,155 \% \text { of normal } \\
148,127 \% \text { of normal } \\
804,121 \% \text { of normal }\end{array}$ \\
\hline Cytochrome $c$ reductase & $\begin{array}{l}\mathbf{1} \\
\mathbf{2} \\
\mathbf{3}\end{array}$ & $\begin{array}{l}275 \\
145 \\
180\end{array}$ & $\begin{array}{l}92,33 \% \text { of normal } \\
\mathbf{3 8}, 26 \% \text { of normal } \\
60,33 \% \text { of normal }\end{array}$ \\
\hline
\end{tabular}

Table 2. Effect of riboflavin deficiency on flavoprotein enzymes in the mycelium of Neurospora crassa mutant grown at $30^{\circ}$

\begin{tabular}{|c|c|c|c|c|}
\hline \multicolumn{5}{|c|}{ (Mean of 4 experiments) } \\
\hline & $\underset{\text { Normal }}{A}$ & $\begin{array}{c}\text { B } \\
\text { Riboflavin- } \\
\text { deficient } \\
\text { mycelia }\end{array}$ & \multirow{3}{*}{$\begin{array}{l}\mathrm{B} \text { as } \\
\% \text { of } \mathrm{A}\end{array}$} & \multirow{3}{*}{$\begin{array}{l}\text { FAD added in vitro } \\
\text { to extracts of } \\
\text { riboflavin deficient } \\
\text { mycelia } \\
\text { (\% of } \mathrm{A})\end{array}$} \\
\hline & \multicolumn{2}{|c|}{$\begin{array}{l}\text { Units of enzyme } \\
\text { activity/mg. protein }\end{array}$} & & \\
\hline PNH diaphorase & 975 & 485 & & \\
\hline I diaphorase & 783 & 242 & 81 & 79 \\
\hline rate reductase & $19 \cdot 4$ & $\mathbf{2 . 0}$ & 10 & 10 \\
\hline Yitrite reductase & 15 & $2 \cdot 5$ & 16 & 94 \\
\hline
\end{tabular}

Table 3. Effect of riboflavin deficiency on 'phosphate' enzymes in the mycelium of Neurospora crassa mutant grown at $30^{\circ}$

$\begin{array}{ccccc}\begin{array}{c}\text { Enzyme } \\ \text { from }\end{array} & \text { Phosphatase } & \begin{array}{c}\text { Hexokinase } \\ \text { Units of enzyme/mg. protein }\end{array} & \begin{array}{c}\text { Phosphorylase } \\ \text { Phosphoglucomutase }\end{array} \\ \begin{array}{c}\text { Control } \\ \text { mycelium }\end{array} & 1.65 & 130 & 1.09 & 2.14 \\ \begin{array}{c}\text { Riboflavin- } \\ \text { deficient } \\ \text { mycelium }\end{array} & 1.50 & 180 & 1.08 & 1.83 \\ & & & & \end{array}$

\section{DISCUSSION}

A temperature-sensitive mutant of Neurospora crassa is shown to have an absolute requirement for riboflavin when grown at $30^{\circ}$, but this is markedly less exacting when grown at $25^{\circ}$. The reason for the different requirement for the vitamin at the two temperatures cannot be explained in terms of a decrease in amount of flavoprotein enzymes in the fungus grown at $25^{\circ}$. In fact there 
is no difference between the activity of the flavoprotein enzymes in the mutant grown at the two temperatures so that riboflavin must be synthesized from its precursors in the fungus at $25^{\circ}$ (unpublished result).

There is a similar requirement for $\mathrm{Fe}, \mathrm{Zn}, \mathrm{Cu}, \mathrm{Mn}$ and $\mathrm{Mo}$ in the wild type 146 and for the mutant grown at $25^{\circ}$ or $30^{\circ}$. It seems unlikely therefore that these metals are involved in the biosynthesis of riboflavin in the mutant.

The results of enzyme assays of the mutant grown at $30^{\circ}$ with optimal and deficient concentrations of riboflavin demonstrate alternative mechanisms for electron transport in the mould. When riboflavin is deficient two iron enzymes (peroxidase and cytochrome oxidase) are produced in large amounts and oxygen is probably the terminal electron acceptor because the flavoprotein enzymes, nitrate and nitrite reductases, are considerably diminished in quantity. The TPNH and DPNH diaphorase systems and cytochrome $c$ reductase, which are flavin dependent, are alsc much decreased in amount when riboflavin is deficient. Iron deficiency is more readily produced in riboflavindeficient mycelium, when the iron enzymes are produced in quantity, and the Mo requirement is greater when the riboflavin concentration is optimal, the flavoprotein enzymes then being very active. Thus the electron transfer mechanism of this organism involves an iron system when riboflavin is deficient and a molybdoflavoprotein system when the riboflavin concentration is optimal. The effects of $\mathrm{Fe}$ and Mo deficiencies on electron transfer in the fungus are similar to those reported for Pseudomonas fluorescens by Lenhoff, Nicholas \& Kaplan (1956).

The effect of FAD (boiled pig heart) or FMN in reactivating the DPNH and TPNH diaphorase systems and nitrite reductase in extracts of riboflavindeficient mycelium shows that their apoenzymes are unaffected by riboflavin deficiency. A shortage of riboflavin did not affect the flavoprotein enzymes to the same degree; thus nitrate and nitrite reductases are more markedly decreased in amount than are the DPNH or TPNH diaphorase systems. This may be explained in terms of a greater affinity of the apoenzyme of some flavoproteins for the flavin nucleotides available; the ones having the greatest affinity would retain their activity longest.

Thanks are due to Miss Elizabeth Atkinson who assisted with the preparation of pure cultures of the mutant and with the determination of the enzymes in the fungus described in this paper.

\section{REFERENCES}

Bessey, O. A., Lowry, O. H. \& Brock, M. J. (1946). A method for the rapid determination of alkaline phosphatase with five cubic millimetres of serum. J. biol. Chem. 164, 321.

Crane, R. K. \& Sols, A. (1953). Animal tissue hexokinases, in Methods in Enzymology, I, p. 277. Ed. Colowick, S. P. \& Kaplan, N. O. New York: Academic Press.

Feinstein, R. N. (1949). Perborate as substrate in a new assay of catalase. J. biol. Chem. 180, 1197.

Lenhoff, M. H., Nicholas, D. J. D. \& Kaplan, N. O. (1956). Effects of oxygen, iron, and molybdenum on alternative routes of terminal electron transfer in Pseudomonas fluorescens. J. biol. Chem. 220, 983. 
Mrtchell, H. K. \& Houlahai, M. B. (1946). Neurospora (IV). A temperaturesensitive riboflavinless mutant. Amer. J. Bot. 33, 31.

NaJjar, V. A. (1955). Phosphoglucomutase from muscle, in Methods in Enzymology, 1, p. 294. Ed. Colowick S. P. \& Kaplan, N. O. New York: Academic Press.

Nason, A. \& Zucker, M. (1956). Nitroaryl reductase from Neurospora crassa, in Methods in Enzymology, II, p. 406. Ed. Colowick, S. P. \& Kaplan, N. O. New York: Academic Press.

Nicholas, D. J. D. (1952). The use of fungi for determining trace metals in biological materials. Analyst, 77, 629.

Nicholas, D. J. D. \& Nason, A. (1954). Mechanism of action of nitrate reductase from Neurospora. J. biol. Chem. 211, 183.

Pullman, M. E., Colowick, S. P. \& Kaplan, N. O. (1954). Comparison of diphosphopyridine nucleotide with its deaminated derivative in various enzyme systems. J. biol. Chem. 194, 593.

Robinson, H. W. \& Hogden, C. G. (1940). Biuret reaction in determination of serum proteins. J. biol. Chem. 135, 727.

Smith, F. G., Robinson, W. B. \& Stotz, E. (1949). A colorimetric method for the determination of peroxidase in plant material. J. biol. Chem. 179, 881.

Sмrтн, F. G. \& Stotz, E. (1949). A colorimetric method for the determination of cytochrome oxidase. J. biol. Chem. 179, 891.

Whelan, W. J. (1955). Phosphorylases from plants in Methods in Enzymology, r, p. 192. Ed. Colowick, S. P. \& Kaplan, N. O. New York: Academic Press. 